Sciendo Порівняльна професійна педагогіка 9(3)/2019 Comparative Professional Pedagogy 9(3)/2019

DOI: $10.2478 / \mathrm{rpp}-2019-0030$

Intern in Regional Institute of Social Work Aquitaine, Bordeaux (France),

SERGIY YASHCHUK

The National University of Life and Environmental Sciences of Ukraine Address: 16-a Heroyiv Oborony St., Kyiv, 03041, Ukraine

E-mail: sergiolife92@gmail.com

\title{
EDUCATIONAL MANAGEMENT \\ IN THE REGIONAL INSTITUTE OF SOCIAL WORK AQUITAINE
}

\begin{abstract}
The article analyzes the organization of the educational process in the Regional Institute of Social Work Aquitaine. It is found that the following departments of the Institute are responsible for organizing the educational process: the department of initial professional training in social work; the department of constant social formations; the department of management training; the research department; the centre for social action learning; the department of internal educational operations; the department of the educational process and symposia; the department of international activities; the centre for evaluation of skills in social professions; the centre for validation of acquired experience in social work. It is revealed that the Regional Institute of Social Work Aquitaine will be merged into the University of Bordeaux between 2019 and 2020 and become part of the National Union of Training and Research in the field of social intervention, which integrates all types of training in social work. The Regional Institute of Social Work Aquitaine is also under the direction of the Regional Association of Social Work. It must be noted that the Regional Institute of Social Work Aquitaine provides the protocol for certification and testing of the Level 3 Modules (ASS / ES / EJE / ETS / CESF). After all, the general conditions of this protocol ensure the support of candidates for such certification and testing. These conditions include the location of certification and testing; instructions and criteria: an invitation to certification and testing, the organization of certification and testing, the organization of module certification, the information about certification and testing committee, the submission of results from certification and testing (results of certification and testing, absence of candidates during certification and testing, module testing, violations and protection means).
\end{abstract}

Keywords: social work, organization, social worker, educational management, social school, project, internship, legal approach.

\section{АНОТАЦІЯ}

Проаналізовано організацією освітнього процесу Соиіальної школи IRTS Нової Аквітанії. Визначено, щчо організацією освітнього процесу займаються відділи соціальної школи IRTS: початкової професійної підготовки з соиіальної роботи; постійних соціальних формувань; навчання з менеджменту; досліджень та Навчальний иентр із вивчення сочіальних дій; внутрішніх навчальних утворень; організачії освітнього процесу та навчальних симпозіумів; міжнародної діяльності; центр оцінки навичок для соиіальних професій; иентр валідації придбаного досвіду в соиіальній роботі. 3'ясовано, шео Соціальна школа з 2019-2020 н. р. ввійде до складу університету м. Бордо як Інститут та стане частиною Національного Союзу Тренінгів та Досліджень у 
sciendo Порівняльна професійна педагогіка 9(3)/2019

Comparative Professional Pedagogy 9(3)/2019

галузі соиіальної інтервениії, яке об'єднує всі види навчання з сочіальної роботи. Сочіальна школа IRTS Нової Аквітанї знаходиться також під керівництвом нової Регіональної асоціації соціальної роботи IRTS. Регіональний інститут соціальної роботи Нова Аквітанія надає Протокол випробувань сертифікації та перевірки модулів рівня 3 (ASS / ES / EJE / ETS / CESF), організований Сочіальною школою IRTS Новоі Аквітанії. Обгрунтовано, щуо в загальних умовах Протоколу випробувань сертифікації та перевірки модулів рівня 3 (ASS / ES / EJE / ETS / CESF) визначена підтримка кандидатів на проведення сертифікаційних випробувань. Загальні умови Протоколу випробувань сертифікачіï та перевірки модулів рівня 3 (ASS / ES / EJE / ETS / CESF) містять: місие експертизи, Інструкиії та критерії: запрошення на сертифікаиійні випробування, організащія сертифікаційних випробувань, організачія тестування валідаціі модуля, інформацію журі про сертифікаційні випробування, подача результатів сертифікаційних випробувань: передача результатів перевірки, відсутність кандидатів під час випробувань, випробування з перевірки модуля, правопорушення та засоби захисту.

Ключові слова: сочіальна робота, організачія, сочіальний прачівник, освітній менеджмент, сочіальна школа, проект, стажування, правовий підхід.

\section{INTRODUCTION}

Aquitaine was proclaimed a province in 1901. The Regional Institute of Social Work Aquitaine (Bordeaux, France) was established in 1974 by merging three schools of social work and a centre for the professional development of this sector. Its missions are defined by the Ministerial Decree as of 22 August 1986. The following departments of the Institute are responsible for organizing the educational process: the department of initial professional training in social work; the department of constant social formations; the department of management training; the research department; the centre for social action learning; the department of internal educational operations; the department of the educational process and symposia; the department of international activities; the centre for evaluation of skills in social professions; the centre for validation of acquired experience in social work (l'IRTS, 2019).

The Regional Institute of Social Work Aquitaine will be merged into the University of Bordeaux between 2019 and 2020 and become part of the National Union of Training and Research in the field of social intervention, which integrates all types of training in social work. The Regional Institute of Social Work Aquitaine is also under the direction of the Regional Association of Social Work. There are now two colleges affiliated with the Regional Institute of Social Work Aquitaine which train social workers and social policymakers ('IRTS, 2019).

The Regional Institute of Social Work Aquitaine has launched an important professional collaboration project between the Social and Medical Faculty of the Institute (Year 2) and the Health Institute (Year 3). At the premises of University Hospital of Bordeaux, hospitals in Libourne, Bagatel, Croix Rouge and Charles Perren's hospital centre, nurses will do internships in the following fields: physiotherapy, psychomotor therapy, occupational therapy, cosmetology, paediatrics. The total enrollment in the medical social course totalled 1099 students in the 2018-2019 academic year. The objectives of the Regional Institute of Social Work Aquitaine in regard to the professional medical social project include the following: to define educational courses, professions, areas of operation, missions and relevant skills with the help of students from the Social and Medical Faculty; to determine the boundaries between professional collaboration due to 
joint activities aimed at studying a certain situation or developing a project; to organize the educational process: trips and both coordination and complementarity of the participants. The students need to study for 5 days, 7 hours a day (35 hours). It must be noted that 72 groups (12-20 students) were formed in different educational institutions participating in the project. The requirements for registration in groups are as follows: students are conditionally assigned to one of the groups (taking into account the representativeness of each course according to the topic); since September, these groups are available on the ecampus: topic-specific, structural and educational courses; there is also an opportunity for exchange between the students of the group by applying to the e-campus: to indicate the name, the name of the group and the institution involved in the exchange; students from other cities can be engaged in distance learning (Zhuravska, 2010; l'IRTS, 2019).

As for the Regional Institute of Social Work Aquitaine, the assessment is taken into account when assessing the student's educational path (at the end of the year). The results of each group will be assessed collectively based on their presentation. The students present their training and working skills on the first day: they receive training recommendations. The group score for medical students from the Institute is confirmed by the assessment scale adopted in the European Union.

\section{THE AIM OF THE STUDY}

The article aims to analyze the organization of the educational process in French social schools, in particular in the Regional Institute of Social Work Aquitaine.

\section{THEORETICAL FRAMEWORK AND RESEARCH METHODS}

Scientific findings of such university teachers as L. Viktorova, V. Korenshchuk, S. Nikolaienko, V. Shynkaruk, J. Lagaillarde, V. Lascaut, Y. Meunier, C. Pellicer, L. CésarFranquet are focused on the characteristics of training social workers. In order to achieve the aim of the study, the following research methods were used: analysis and generalization of empirical and theoretical provisions contained in the professional and reference literature in various scientific fields (pedagogy, psychology, sociology, jurisprudence, teaching methods, social work, etc.) and in the works of Ukrainian and foreign researchers.

\section{RESULTS}

The Regional Institute of Social Work Aquitaine provides the protocol for certification and testing of the Level 3 Modules (ASS / ES / EJE / ETS / CESF). After all, the general conditions of this protocol ensure the support of candidates for such certification and testing. These conditions include the support of candidates for certification and testing (information, equal opportunities); the harmonization of assessment and correction (types and choice of topics, assessment criteria and correction indicators); the renewal (certification repository) and adequacy of the suggested educational projects; the qualitative support of the committee members (Shynkaruk, 2017, pp. 156-158; 1'IRTS, 2019).

They also include the following:

1. The location of certification: the site of internal assessment (amphitheatre, rooms on the same floor according to availability) is determined and assigned at the time of certification. It makes it possible to offer the candidates optimal conditions for checking the quality of certification (silence). The candidates are observed by persons appointed by the Regional Institute of Social Work Aquitaine. The selection of candidates is anonymous. The training organization informs the subject about its candidates. The tag team is mobilized (grouped in one place) in case of event certification. Some certification tests in exceptional situations may take place in professional institutions (Brugere, 2011; 1'IRTS, 2019). 
2. Instructions and criteria, characteristic of each certification, organized into educational courses, as well as certification dates, results reports and their modalities presented to students and trainees according to the specific learning conditions.

3. An invitation to certification: for each of these events, the date, time and venue will be confirmed by a letter addressed to the candidate by name, that is from 15 days to one month before the date specified for certification. This letter is a notification of the certification date and must be received by the applicant personally.

4. The organization of certification: the committee is run by the head of the education department, who confirms the choice of subjects, date, purpose and course of the event so that the subjects for written tests can be chosen (Bouquet, 2012). The calendar and expected events for all written, oral and practical tests will be presented to students before the start of the study on the qualification page or in the Regional Institute of Social Work Aquitaine.

This protocol also contains the expectations of certification and target indicators of skills; the arrangements for certification: location, duration, designation and coefficient, the number of proofreaders or requests: assessment criteria, ranking data sheets and correction methods.

5. The organization of module validation testing: teaching methods as well as distance learning methods listed on the module sheets and available on the e-campus.

6. The information about certification and testing committee: the protocol is addressed to the committee members as well as to the committee chair and provides written confirmation of their participation. This document contains the expectations of certification and target indicators of skills; the arrangements for certification: location, duration, designation and coefficient, the number of proofreaders or requests: assessment criteria, ranking data sheets and correction methods.

Before certification, each committee member receives the supporting documents required for it (workplace policies, assessment cards) and an explanatory note on the use of these documents (Boyer, 2001; l'IRTS, 2019). Assessment instructions are given according to the grade level (ASS / ES / EJE / ETS / CESF). The name, surname, signature and quality of the proofreader will be indicated, too.

To harmonize the certification process, a meeting with a training manager and / or a module manager is organized daily before written or oral testing. The final assessment committee (chaired by the cluster manager by the delegation of the institution's CEO) completes the certification day and submits to each committee the results of the written and/or oral examination and notifies the candidates.

7. The quality of the committee members during certification and testing: the committee members are mobilized among the specialists of the Regional Institute of Social Work Aquitaine (due to their professional focus and / or hierarchy of sites that are qualified and / or involved in the process of supporting multiple listeners); external pedagogical agents of the New Aquitaine region who fit into the pedagogical framework according to the grade level (ASS / ES / EJE / ETS / CESF); the representatives of decentralized administrations.

8. Special cases: the applicants whose individual situation justifies adjustments to assessment conditions (room availability, physical assistance) should request a meeting with a trainer a month before the study so that one can create a file for teaching courses (Ladriere, 1991; l'IRTS, 2019).

9. The submission of results from certification: the results obtained by students at each certification session of the trainees are presented by the Assessment Centre of the Regional Institute of Social Work Aquitaine as the organizer of certification (except for 
notes submitted at the end of the course in accordance with the regulatory requirements of DRJSCS educational standards and / or the Rectorate) (Dreano, 2009). The applicants who have not received the intermediate certification test organized by the Institute will continue their training following the specific terms of the diploma by submitting the certificate to the previous declaration. They may, by e-mail, contact the Director of the Assessment Centre and request a copy of the protocol for the assignment of their test scores. Module Managers or Training Managers (DCs) have access to the grades listed on the test results reference sheets for pedagogical purposes and can monitor student performance.

10. The submission of certification results: the results are submitted no later than 10 days after the procedure.

11. The absence of candidates during certification: any absence of candidates for valid reasons requires the confirmation by submitting an official document within 48 hours after the examination. An arbitrary session may then be offered following the contractual arrangements of the candidates who are subject to these conditions.

12. Module certification: all modules are eligible for a reminder session. This is done when the student did not receive the average during the first session or in case of his/her absence for a medical reason. An unjustified absence at the first certification session or a zero score does not give access to the "catch-up" session.

13. Violations: Any violation of the certification protocol, as well as plagiarism and fraud, will be sanctioned by the Disciplinary Committee of the Institute and may result in the prohibition of state diploma certification tests (Yashchuk, 2016, pp. 333-339; Dreano, 2019).

14. Precaution means: the board of appeal consists of the leadership of the Regional Institute of Social Work Aquitaine, the company's manager, a group of trainers, a professional judge and a representative of students and / or trainees. The board of appeal should be chaired by the institution's CEO which is established after the written request of the candidate concerned by the dispute. The zero score must be awarded to the student for any work not completed before the specified date.

Educational resources of the Institute include educational projects, trainers responsible for further education, educational courses, individual educational courses, educational groups, teaching offices, assistants in the administration of education, the certification centre of participants, a documentary centre, methodological offices: works, reviews, memoir counsels, copiers, e.campus.

Article 6 of the Rules adopted by the Regional Institute of Social Work Aquitaine reflects the certification of higher and continuing education. The certification process is considered valid if the student has fulfilled the conditions set out in the regulatory documents. The permission to move from one year of study to another, suspension or termination of the study, other than disciplinary, is subject to the orders of the Rectorate of the Institute. ECTS credits are issued at the end of the year by the certification committee.

\section{CONCLUSIONS}

Based on the analysis of scientific and reference sources, it is found that the rules of the Regional Institute of Social Work Aquitaine reflect: Article 5 - the initial training certification - educational courses with ECTS credits, Level 3 training taking into account the European Regulations and ECTS. ECTS-based learning is confirmed, on the one hand, by students, trainees or students studying under the conditions laid down in the regulations and, on the other hand, meets the requirements of the module certification. Module approval is the responsibility of the semi-annual review commission. The Commission resolves the issue of module approval after studying the file by students, trainees or pupils. 
In exceptional circumstances, the commission may propose the opposite solution to what was originally planned. The two-year certification committee consists of the department manager, the head of the assessment centre and an employee responsible for education in the Rectorate. The commission meets within 2 months after the end of each six months. The organization of all certifications and audits is formulated as part of a document called "the audit and certification protocol". It is stated that Article 7 of the rules of the Regional Institute of Social Work Aquitaine, namely the approval and certification protocol, specifies the methods of organization associated with the tests submitted to the Institute. Article 8, namely the transfer commission, states that the purpose of the transfer committee is to process requests for transfer of students, trainees and students from another training centre to the assessment centre of the Institute. After processing the files studied by the students, a proposal is made to the senior management of the Rectorate for final review (it meets once a year).

The prospects for further research should lie in the analysis of scientific materials on socio-cultural management in French social schools and their implementation in Ukraine.

\section{REFERENCES}

1. Bouquet, B. (2012). Ethique et Travail social une recherche du sens. Paris: Dunod.

2. Boyer, A. (2001). Guide Philosophique pour penser le travail éducatif et médicosocial. Paris: Erès.

3. Brugere, F. (2011). L'éthique du care. Paris: PUF.

4. Dreano, G. (2009). Guide de l'éducation spécialisée. Paris: Dunod IFSW.

5. Ladriere, P. (1991). L'éthique soi et les autres. Informations sociales, 9, 10-18.

6. l'IRTS. (2019). Retrieved from http://www.campus-irts.fr.

7. Merlier, P. (2013). Philosophie et éthique en travail social. Rennes: Presses de l'EHESP.

8. Shynkaruk, V. D. (2017). Aspekty ukrainsko-polskoi spivpratsi v haluzi osvity $i$ nauky. Materialy Mizhnarodnoi naukovo-praktychnoi konferentsii "Ukraina - Polshcha: stratehichne partnerstvo v systemi heopolitychnykh koordynat”. Kyiv: UIZh.

9. Yashchuk, S. P. (2016). Formuvannia profesiino-pravovoi kompetentnosti studentiv. Naukovyi visnyk Natsionalnoho universytetu bioresursiv i pryrodokorystuvannia Ukrainy. Seriia: Pedahohika psykholohiia filosofiia, 253, 333-339.

10. Zhuravska, N. S. (2010). Metodolohiia proektuvannia interaktyvnykh kursiv na osnovi yevropeiskoho dosvidu. Kyiv: NAU. 